CHEMICAL SEPARATIONS PROCESSES

FOR PLUTONIUM AND URANIUM

(TID-4500, 16th Ed.)

\title{
EVALUATION OF HYDROCARBON DILUENTS FOR THE PUREX PROCESS
}

\author{
by \\ Burton P. Dennis and David L. West \\ Work done by \\ B. P. Dennis \\ J. W. Nehls \\ R. S. Ondrejcin \\ D. L. West
}

R. N. Wilhite

November 1961

\author{
E. I. du Pont de Nemours \& Co. \\ Explosives Department - Atomic Energy Division \\ Technical Division - Savannah River Laboratory \\ Printed for \\ The United States Atomic Energy Commission \\ Contract $\operatorname{AT}(07-2)-1$
}




\section{DISCLAIMER}

This report was prepared as an account of work sponsored by an agency of the United States Government. Neither the United States Government nor any agency Thereof, nor any of their employees, makes any warranty, express or implied, or assumes any legal liability or responsibility for the accuracy, completeness, or usefulness of any information, apparatus, product, or process disclosed, or represents that its use would not infringe privately owned rights. Reference herein to any specific commercial product, process, or service by trade name, trademark, manufacturer, or otherwise does not necessarily constitute or imply its endorsement, recommendation, or favoring by the United States Government or any agency thereof. The views and opinions of authors expressed herein do not necessarily state or reflect those of the United States Government or any agency thereof. 


\section{DISCLAIMER}

Portions of this document may be illegible in electronic image products. Images are produced from the best available original document. 


\begin{abstract}
Forty-nine hydrocarbon products were evaluated in the laboratory in a search for a highly stable diluent for the organic extractant used in a radiochemical separations plant. The formation of zirconium ligands during chemical and radiolytic degradation increased with bolling point for 1soparaffinic products but was approximately constant for n-paraffins. Of those materials that met the local flash point specification, the $n$-paraffins were superior.
\end{abstract}




\section{CONTENTS}

$\underline{\text { Page }}$

List of Figures

4

Introduction $\quad 5$

$\begin{array}{ll}\text { Summary } & 6\end{array}$

Discusion $\quad 6$

Experimental Methods 6

Comparative Stabilities 7

Relationship Between Stability and Compound Class 7

Relationship Between Stability and Volat1l1ty 11

$\begin{array}{ll}\text { Bibliography } & 13\end{array}$

Append1x A - Gas Chromatograms of the Hydrocarbon Diluents 14

Append1x B - Infrared Spectrograms of Selected Diluents 24

Appendix C - Ultraviolet Spectrograms of Selected Diluents 28

Appendix D - Statistical Analysis of Stability Ratios 31

\section{LIST OF TABLES}

Table

I Comparative Stability and Physical Properties of Hydrocarbon Products

II Stability and Volatility of Isoparaffins 


\section{LIST OF FIGURES}

$\underline{\text { Figure }}$

$\underline{\text { Page }}$

1 Zirconium Ligand Formation as a Function of Volatility

2 Effect of Olefin Content on Stability of n-DodecaneTBP Mixture

A-I Gas Chromatograms of Diluents from Radiochemical Separations Plants

A-2 Gas Chromatograms of n-Paraffin Mixtures

A-3 Gas Chromatograms of Distillation Fractions of an Isoparaffin Mixture

A-4 Gas Chromatograms of Isoparaffin Mixtures

A-5 Gas Chromatograms of High Boiling Hydrocarbons

A-6 Gas Chromatograms of Other Candidate Diluents 22

B-1 IR Spectrograms of Diluents from Radiochemical Separations Plants

B-2 IR Spectrograms of n-Paraffin Mixtures 26

B-3 IR Spectrograms of Isoparaffin Mixtures 26

B-4 IR Spectrograms of Other Candidate Diluents 27

C-1 UV Spectrograms of Diluents from Radiochemical Separations Plants

C-2 UV Spectrograms of n-Paraffin Mixtures

C-3 UV Spectrograms of Isoparaffin Mixtures 30

C-4 UV Spectrograms of Other Candidate Diluents 30 


\section{EVALUATION OF HYDROCARBON DILUENTS FOR THE PUREX PROCESS}

\section{INTRODUCTION}

The Purex process is a solvent extraction process employed at the Savannah River Plant to separate and recover plutonium and uranium from fission products that form during irradiation of uranium in a nuclear reactor. Tri-n-butyl phosphate (TBP) is used as the organic extractant in the Purex process. The TBP is used as a solution in a hydrocarbon product of which "Ultrasene"*, a purified kerosene, is typical. Unknown components in "Ultrasene" degrade chemically and radiolytically to form ligands that complex zirconium and other fission products $(1,2,3)$. These ligands are not removed from the solvent by either caustic or acidic washes (1) but remain in the solvent and cause operating difficulties. Di-n-butyl phosphate (DBP), the principal zirconium ligand produced by the degradation of TBP, can be removed from the solvent by a caustic wash $(1)$.

A search was conducted for a diluent that would form fewer zirconium ligands. The primary objective of this study was to find a better diluent by evaluating the resistance of commercially available hydrocarbon products to chemical and radiolytic degradation. The number of zirconium ligands formed was a measure of stability. Relationships between stability and composition of the diluent were also studied.

Previous work in the Savannah River Laboratory served as a guide in the selection and evaluation of these diluents. Pollock demonstrated that olefin-free n-dodecane, obtained from Humphrey-Wilkinson, was a superior diluent for the Purex process on the basis of its resistance to chemical attack. (1) West found that the zirconium retention characteristics of the n-paraffins in "Ultrasene", separated from "Ultrasene" by urea treatment, were comparable to those of $n$-dodecane, and were much superior to those of "Ultrasene" itself.(4) The characteristics reported by Dennis for the zirconium retention of certain pure iso- and cycloparaffins indicated that the stabilities of these compounds were comparable to those of $n$-dodecane. (5) on the basis of this information, a diluent composed of normal paraffins and free of olefins and aromatics would be preferable although certain iso- or cycloparafins might also make comparable diluents.

This report describes the evaluation of several commercially available hydrocarbon products that were considered as potential diluents. After this work was complete a British report (6) was issued that described similar studies, but on different diluents.

"Adakane 12" was chosen for plant-scale evaluation in the most severe Purex service at Savannah River. The laboratory evaluation of this $\mathrm{n}$-paraffin mixture is described in a separate report $(\mathbf{7})$.

*the supplier of each diluent is listed in Table I. 
Although "Ultrasene" had served adequately as a Purex diluent in prior normal service at Savannah River, an incentive existed to search for a diluent that might diminish solvent recycle problems to a minimum for a TBP process. Other diluents comparable in stability to "Ultrasene" are also used at other sites, with satisfactory results. Thus, the "stabilities" given in this report cannot be used as absolute criteria of acceptability for any given service; specific needs are complex functions of radiation exposure, chemical exposure, time of contact, unit costs, and the like.

\section{SUMMARY}

The chemical and radiolytic stabilities of $30 \%$ TBP solvents made from nine of the forty-nine hydrocarbon products tested were sufficiently close to those of solvents of olefin-free $n$-dodecane to warrant consideration of these products as high-performance diluents. Of these nine hydrocarbon products with high stabilities only $n$-dodecane and "Adakane 12" had flash points equal to or above the $72^{\circ} \mathrm{C}$ minimum that is specifled for the process at the Savannah River Plant (SRP). The other seven hydrocarbon products of high stability were mixtures of $\mathrm{C}_{11}-\mathrm{C}_{15}$ 1soparaffins. Formation of zirconium ligands in isoparaffinic materials increased with bolling point, and a fraction with a boiling point high enough to have a satisfactory flash point offered little more stability than the "Ultrasene" diluent presently in use at SRP. Correlations were observed between stability and boiling point as well as between stablitty and compound class.

\section{DISCUSSION}

\section{EXPERIMENTAL METHODS}

The criterion for stability in this study was the resistance of the diluent to degradation to form zirconium ligands. Each of the candidate diluents was tested for chemical and radiolytic stability as a 30 vol \% TBP solvent. The TBP was added to approximate more closely the plant environment for exposure to radiation and acids.

Allquots of the solvents were degraded in contact with $4 \mathrm{M} \mathrm{HNO} 3-0.1 \mathrm{M} \mathrm{HNO}_{2}$ elther chemically for 7 days at $70^{\circ} \mathrm{C}$ or radiolytically to $10^{7}$ rep by exposure to a beta-gamma source. The degraded samples were then washed successively with distilled water, $1 \mathrm{M} \mathrm{NaOH}$, distilled water, $1 \mathrm{M} \mathrm{HNO}_{3}$, and distilled water. The washed samples were tested for zirconium retention by means of the "Z Test".(B) Detalled descriptions of the degradation and washing procedures were given in an earlier report ${ }^{4}$.

Solvents prepared from olefin-free $n$-dodecane and "Ultrasene" were employed as controls in all of the stabli1ty tests. The stability ratios (shown in Table I) are the ratios of the " $Z$ " numbers obtained for solvents made with each diluent to the " $z$ " numbers obtained for solvents made with $\mathrm{n}$-dodecane. On this basis the best diluents are those with lowest stability ratios. 
Gas-liquid chromatography (GLC) was utilized to characterize each of the diluents. A description of the experimental techniques and chromatograms of all the candidate diluents are in Appendix A. The chromatograms are calibrated for bolling points of the components. (4)

Selected samples were analyzed by infrared and ultraviolet spectrophotometry, low ionizing voltage mass spectrometry $(\theta)$, and Fluorescent Indicator Adsorption (FIA). The infrared and ultraviolet spectrograms, which provide further indication of sample purity, are described in Appendix $B$ and Appendix $C$, respectively. Flash points were determined by Tag closed cup(10). Fluorescent Indicator Adsorption analyses were done according to ASTM D-1319-60T (11).

\section{COMPARATIVE STABILITIES}

The stabilities and physical properties of hydrocarbon products obtained from commercial sources are compared to those properties of $n$-dodecane and "Ultrasene" in Table $I$. The stability ratios provide a measure of the resistance of the diluent to degradation to form zirconium ligands (the higher the ratio, the lower the stability). Specifications required the flash point of the diluent to be a minimum of $72^{\circ} \mathrm{C}$ and the specific gravity to be a maximum of 0.79 . Although candidate diluents are listed in order of decreasing resistance to chemical degradation, care must be taken when comparing diluents whose stability ratios differ by a small amount. In order to make such a comparison easier, a summary of the precision of stability ratios is given in Appendix D. From the data in this table and the "student's" $t$ value ${ }^{(14)}$ corresponding to the number of determinations, the confidence limits at any desired probability level can be calculated. However, for the purpose of this study a detailed statistical analysis was not considered necessary since the stability tests were designed to select candidates for further consideration, and, therefore, minute differences in stability were not considered to be significant.

Only those candidate diluents with chemical stability ratios less than 15 and radiolytic stability ratios less than 1.1 were given further consideration. Of the diluents meeting these requirements, only "Adakane 12", a mixture of n-paraffins derived from 1 -dodecanol, and $n$-dodecane had measured flash points at or above the required $72^{\circ} \mathrm{C}$ minimum. Ashland R-13 had a nominal flash point that met specifications, but insufficient sample was available to determine a flash point. However, a flash point of $67^{\circ} \mathrm{C}$ was obtained for Ashland $\mathrm{R}-22$, a sample that had a nominal flash point identical to R-13. This topic will be discussed in more detail under Relationship Between Stability and Volatility.

\section{RELATIONSHIP BETWEEN STABILITY AND COMPOUND CLASS}

Of the compound classes tested, the $n$-paraffins were the most stable to chemical degradation. The excellent stability of the n-paraffins is shown in Table I and in Figure 1. "Kendall" SN-552a, a hydrocarbon 
TABLE I

Comparative Stab1lity and Physical Properties of Hydrocarbon Products

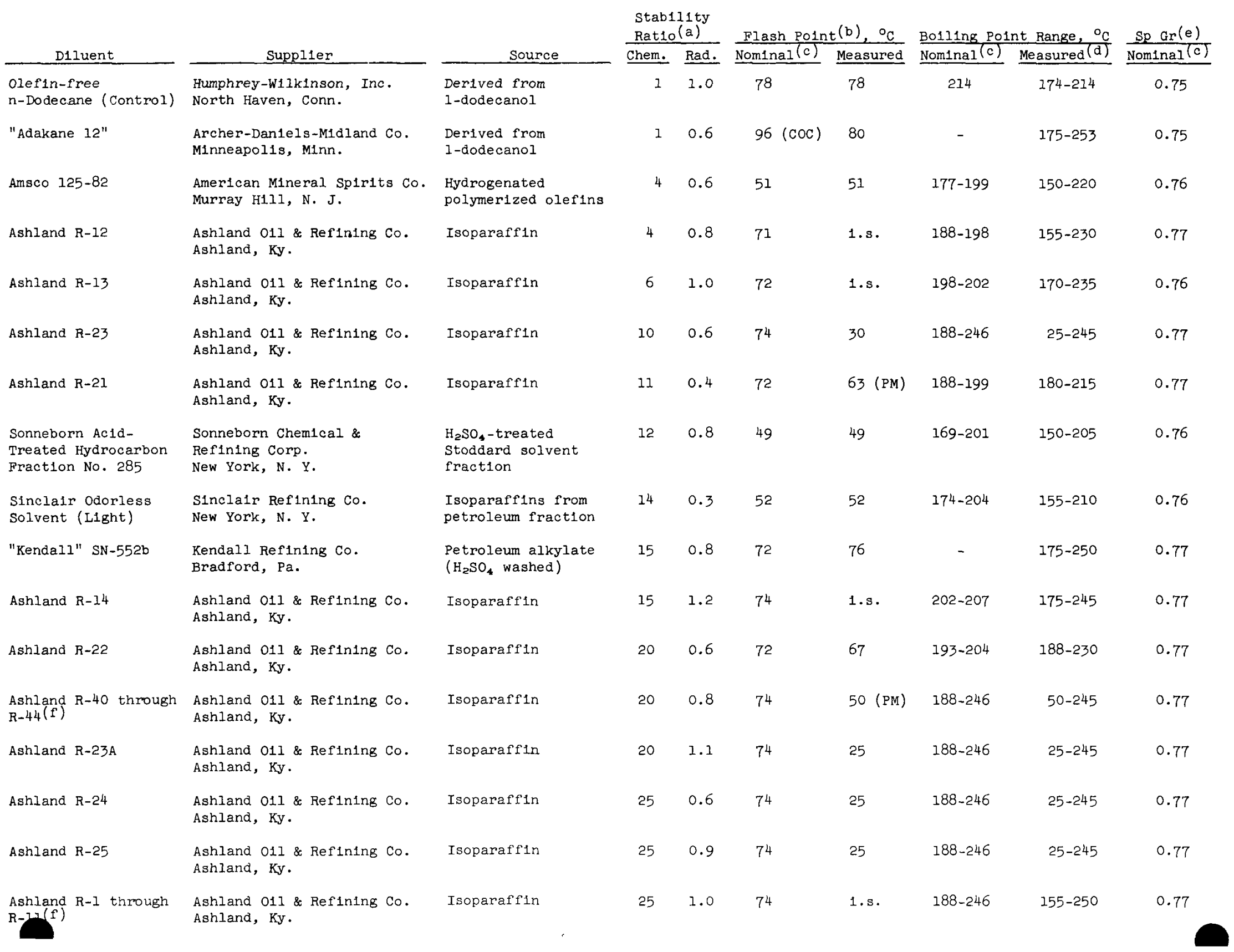


fraction

Ashland $\mathrm{R}-15$

Ashland 011 \& Refining Co.

Isoparaf $f$ in

Ashland R-20 Ashland 011 \& Refining Co.

Isoparaffin

"Kendall" SN-552a

Kendall Refining Co.

n-Paraffins from

Phtllips IsoPhillips Petroleum Co. treatment

paraffinic Fraction Bartlesville, Okla.

\section{Petroleum alkylate}

Ashland $\mathrm{R}-16$

Ashland 011 \& Refining Co.

Isoparaffin

Ashland, Ky.

"Penn-Drake" 2251011

Pennsylvania Refining Co. Butler, Pa.

Raffinate Wash 011

Continental 011 Co Houston, Tex.

Sinclair Odorless

Sinclatr Refining Co.

Solvent (Heavy)

New York, N. Y.

"Ul trasene"

Atlantic Refining Co. Philadelphia, Pa.

Kremol 40 white Mineral oil

\section{Continental $011 \mathrm{Co}$.}

Houston, Tex.

Petroleum distillate

\section{Dearomat1zed $\left(\mathrm{SO}_{2}\right.$
treated) kerosene}

Isoparaffins from

petroleum

$190-237$

$155-245$

Refined kerosene

150

Amsco DeoBase $S$

Shell Chemical Co. (g) New York, N. Y.

JP-5 Aviation Fuel

Texaco Inc.

Petroleum distillate $250 \quad 3.0$

$150-254$ New York, N. Y.

American Mineral Spirits Co. Petroleum distillate 250 Murray H1il, N. J.

Pennsylvania Refining Co.

White o1l from

$400 \quad 5.0$ Butier, Pa.

(a) "Z" number of $30 \%$ TBP $-70 \%$ diluent

(b) Determined by Tag closed-cup method $(10)$ unless noted: PM - Pensky-Martens closed cup(12); COC - Cleveland open cup(13). 1.s. Indicates insufficlent sample

(c) Data furnished by supplier

(d) From gas-11quid chromatograms

(e) Spec1f1c gravity at $25^{\circ} \mathrm{C} / 25^{\circ} \mathrm{C}$

(f) These samples were essentially ldentical. 


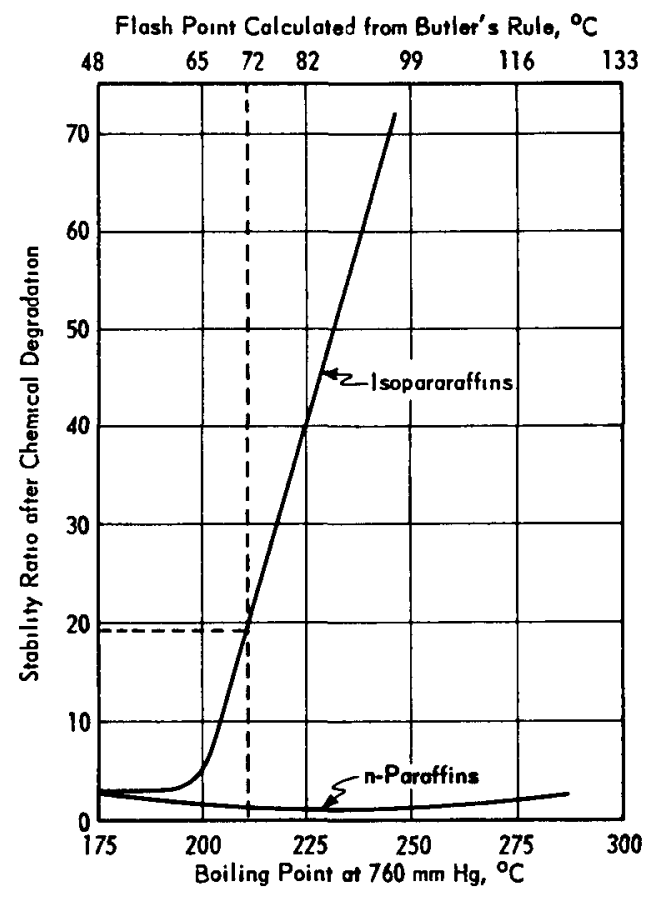

FIG. 1 ZIRCONIUM LIGAND FORMATION AS A FUNCTION OF VOLATILITY

product produced on a laboratory scale by urea treatment of a kerosene fraction, was composed predominantly of $n$-paraffins but had a chemical stablitity ratio of 50 . Previous work (4) showed that such a diluent should be approximately as stable as n-dodecane. The chromatograms of the "Kendall" SN-552a diluent (see Appendix A) showed that this sample contained about 10 wt \% nonlinear components. Subsequent treatment in this laboratory of "Kendall" SN-552a with urea reduced the concentration of nonlinear components to less than 2 wt $\%$ and Improved the chemical stability to the level of olefin-free n-dodecane and "Adakane 12 ".

The stability of the isoparaffins was found to be a function of their volatility and will be discussed in the section on Relationship Between Stability and volatility.

The only sample that was predominantly aromatic, Alkylbenzene 250, was moderately stable to chemical degradation but unstable to radiolytic degradation. This result verified previous work by the authors $(4,5)$.

Although no samples composed predominantly of olefins were tested, Amsco 125-82 contained approximately 1.5 vol \% olefins, probably highly branched olefins. From the previous work of Dennis (5) it was expected that the stability would be decreased by the presence of olefins. In that work, however, degradations were conducted in the absence of TBP. Therefore, the work was repeated with 30\% TBP - 70\% diluent. The curves shown in Figure 2 depict the effect of an olefin, propylene tetramer, on the stability of $n$-dodecane. Mixtures of 1 -dodecene in $n$-dodecane followed the same general curves. Similar results are expected for other olefins although the magnitude of the ligand formation will probably vary with the degree of branching and the bolling point of the olefin in a manner similar to that reported for paraffins in the following section. 


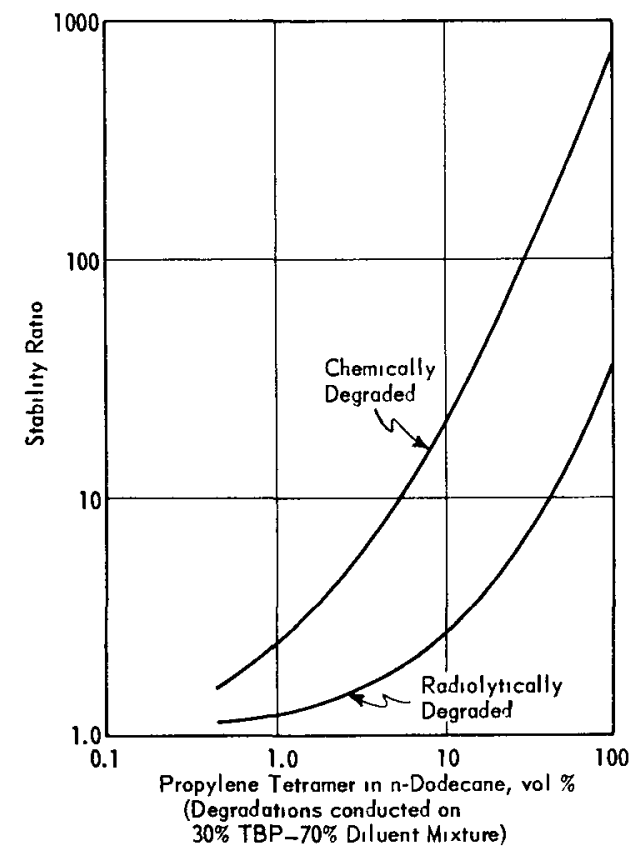

FIG. 2 EFFECT OF OLEFIN CONTENT ON STABILITY OF n-DODECANE-TBP MIXTURE

\section{RELATIONSHIP BETWEEN STABILITY AND VOLATILITY}

A relationship between stabllity and volatility was observed for the isoparaffins supplied by the Ashland 011 and Refining Co. Samples R-l2 through R-16, reported by the suppliers to be distillation cuts from the same base material as samples $R-1$ through $R-11$, showed an inverse relationship between stability and bolling point as seen in Table II.

\section{$\underline{\text { TABLE II }}$}

Stability and Volatillty of Isoparaffins

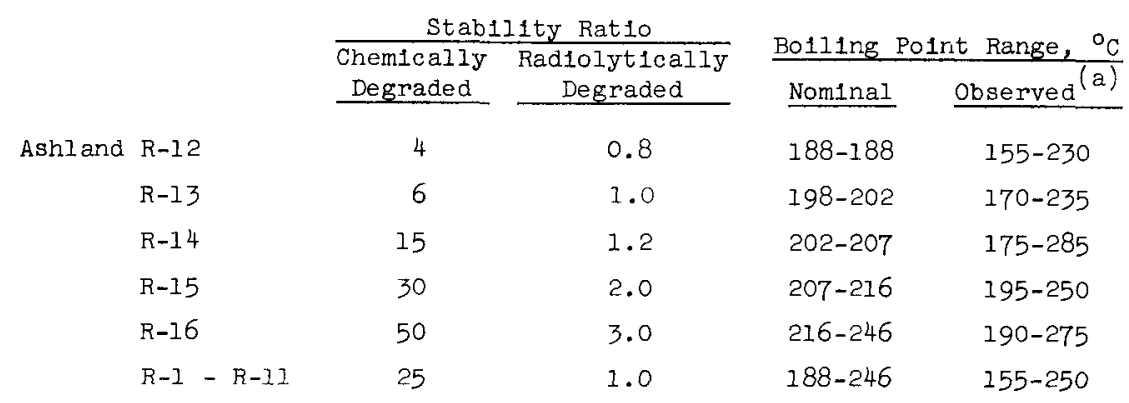

(a) From gas-11quid chromatograms

The dependence of stability upon volatility for 1soparaffins and for $\mathrm{n}$-paraffins is shown in Figure 1. While the stabilities of the n-paraffins were only slightly affected by thelr volatilities, the stabilities of the isoparafifins decreased approximately linearly (stabllity ratio increased) with increase in boiling point over the range 200 to $250^{\circ} \mathrm{C}$. For isoparaffins with bolling points below $200^{\circ} \mathrm{C}$ there was no significant change in the stability ratio. The $n$-paraffinic samples for this study 
were obtained from the National Bureau of standards and contained less than $0.2 \mathrm{~mol} \%$ impurities. The 1soparaffinic samples were fractions with bolling ranges narrower than $6^{\circ} \mathrm{C}$; they were obtained from a fractional distillation of $1500 \mathrm{ml}$ of Ashland sample R-20. The fractionation of this sample was performed by the Petroleum Analytical Research Corporation, Houston, Texas, by means of a 1-1nch-diameter column with 75 theoretical plates at a reflux ratio of $20: 1$.

Since the flash point of an 1soparaffin is directly related to 1 ts volatility (15), the flash point specification at SRP establishes a limiting stability level. According to Butler's rule(15), the temperature at which a hydrocarbon will flash is given by the equation

$$
\mathrm{T}_{\mathrm{F}}=0.683 \mathrm{~T}_{\mathrm{B}}-119
$$

where $\mathrm{T}_{\mathrm{F}}=$ flash point at $I$ atmosphere, ${ }^{\circ} \mathrm{F}$

$$
\mathrm{T}_{\mathrm{B}}=\text { boiling point at } 1 \text { atmosphere, } \mathrm{O}_{\mathrm{F}}
$$

The upper abscissa of Figure 1 was graduated in flash point $\left({ }^{\circ} \mathrm{C}\right)$ by applying the above equation to the bolling points given on the lower abscissa. These data show that a chemical stab1lity ratio of 20 or above is expected for any isoparaffin of the type tested that meets the $72^{\circ} \mathrm{C}$ flash point specification at SRP. If a flash point of $65^{\circ} \mathrm{C}$ or lower were acceptable, an isoparaffinic diluent could be made that was approximately equivalent to the resistance of $n$-paraffins to degradation to zirconium ligands. For 1soparaffinic diluents with flash points above $65^{\circ} \mathrm{C}$, the higher flash points are achieved only by accepting a loss in stability.

The chromatograms of all of the hydrocarbon products evaluated in this study are included in Appendix A. The chromatographic column that was employed separated the components by the differences in their vapor pressures and had no other pronounced selective properties. Therefore, the chromatograms were presented as differential distillation curves with the approximate bolling points of the components in the sample indicated on the abscissa. The area under all of the peaks in each chromatogram is proportional to the weight of material sampled, and the area encompassed between any two temperatures represents the weight of the sampled material that bolls between those two temperatures. These chromatograms, plus the selected infrared and ultraviolet spectrograms, provide a permanent record of the composition and purlty of the materials that were investigated in the course of this work.

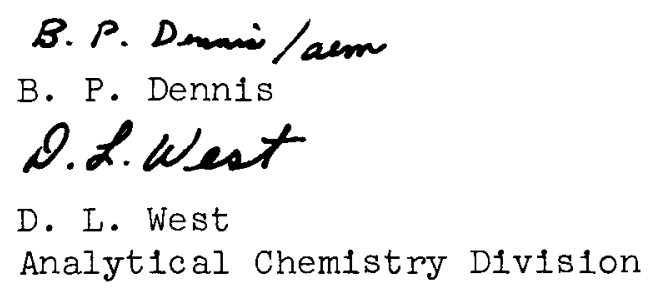




\section{BIBLIOGRAPHY}

1. Pollock, H. A Stable Diluent for Purex Process Extractants. E. I. du Pont de Nemours \& Co., Savannah River Laboratory, Aiken, S. C. AEC Research and Development Report DP-294, 7 pp. (June 1958).

2. Goode, J. H. "How Radiation Affects Organics in Solvent Extraction of Fuel". Nucleonics 15, No. 2, pp. 68-71 (1957).

3. Moore, R. H. Investigation of Solvent Degradation Products in Recycled Uranium Recovery Plant Solvent. General Electric Co., Hanford Atomic Products Operation, RIchland, Wash. AEC Research and Development Report HW-34502 (Rev.), 19 pp. (Apr11 1955).

4. West, D. L. Composition and Stability of "Ultrasene". E. I. du Pont de Nemours \& Co., Savannah River Laboratory, A1ken, S. C. AEC Research and Development Report DP-587, 14 pp. (June 1961).

5. Dennis, B. P. Radiolytic and Chemical Stability of Pure Hydrocarbons. E. I. du Pont de Nemours \& Co., Savannah Rlver Laboratory, Aiken, S. C. AEC Research and Development Report DP-577, 12 pp. (Apr11 1961).

6. Field, B. O. and E. N. Jenkins. Degradation of Diluents Used with TBP in Solvent Extraction. Atomic Energy Research Establishment, Harwel1, Berkshire, England. Research and Development Report AERE-R-3507, 27 pp. (December 1960).

7. Chastagner, P. J. P. Evaluation of "Adakane 12" for Purex Use. E. I. du Pont de Nemours \& Co., Savannah River Laboratory, A1ken, S. C. AEC Research and Development Report DP-601, 12 pp. (October 1961).

8. Garrett, T. P., Jr. A Test for Solvent Quality. E. I. du Pont de Nemours \& Co., Savannah River Laboratory, Aiken, S. C. AEC Research and Development Report DP-237, 16 pp. (August 1957).

9. Wilhite, R. N. Identification of Hydrocarbon Types in "Ultrasene". E. I. du Pont de Nemours \& Co., Savannah River Laboratory, Alken, S. C. AEC Research and Development Report DP-571, 12 pp. (April 1961).

10. "Standard Method of Test for Flash Point by Tag Closed Tester". ASTM Designation: D56-56.

11. "Tentative Method of Test for Hydrocarbon Types in Liquid Petroleum Products by Fluorescent Indicator Adsorption". ASTM Designation: D1319-60T .

12. "Tentative Method of Test for Flash Point by Pensky-Martens Closed Tester". ASTM Designation: D93-58T.

13. "Standard Method of Test for Flash and Fire Points by Cleveland Open Cup". ASTM Designation: D92-57.

14. Youden, W. J. Statistical Methods for Chemists. New York: John Wiley, Chapter $3(1951)$.

15. Penner, S. S. and B. P. Mullins. Explosions, Detonations, Flammability, and Ignition. New York: Pergamon Press, p. 161 (1959). 


\section{GAS CHROMATOGRAMS OF THE HYDROCARBON DILUENTS}

The chromatograms represent the fractionation of 5-microliter samples of each of the diluents with a Perkin-Elmer Model 188 Triple Stage Fractometer. The chromatograph was equipped with a 4-meter column that was packed with silicone grease on "Celite"*. The instrument was operated at $200^{\circ} \mathrm{C}$ with an inlet pressure of $22 \mathrm{psi}$. A thermal conductivity cell was used as a detector. The chromatograms were calibrated for the boiling point of the hydrocarbons so that the time scale on the conventional chromatograms became a temperature scale that represented the bolling point at one atmosphere.

W1th some samples 1t was necessary to attenuate the signal from the detector in order to prevent the recorder pen from driving off scale. In these cases the attenuation is indicated on the chromatogram, e.g. X8, which means the real peak height is eight times that shown on the chromatogram.

The supplier of each diluent is listed in Table I.

*A product of the Johns-Manville Corp., New York, N. Y. 

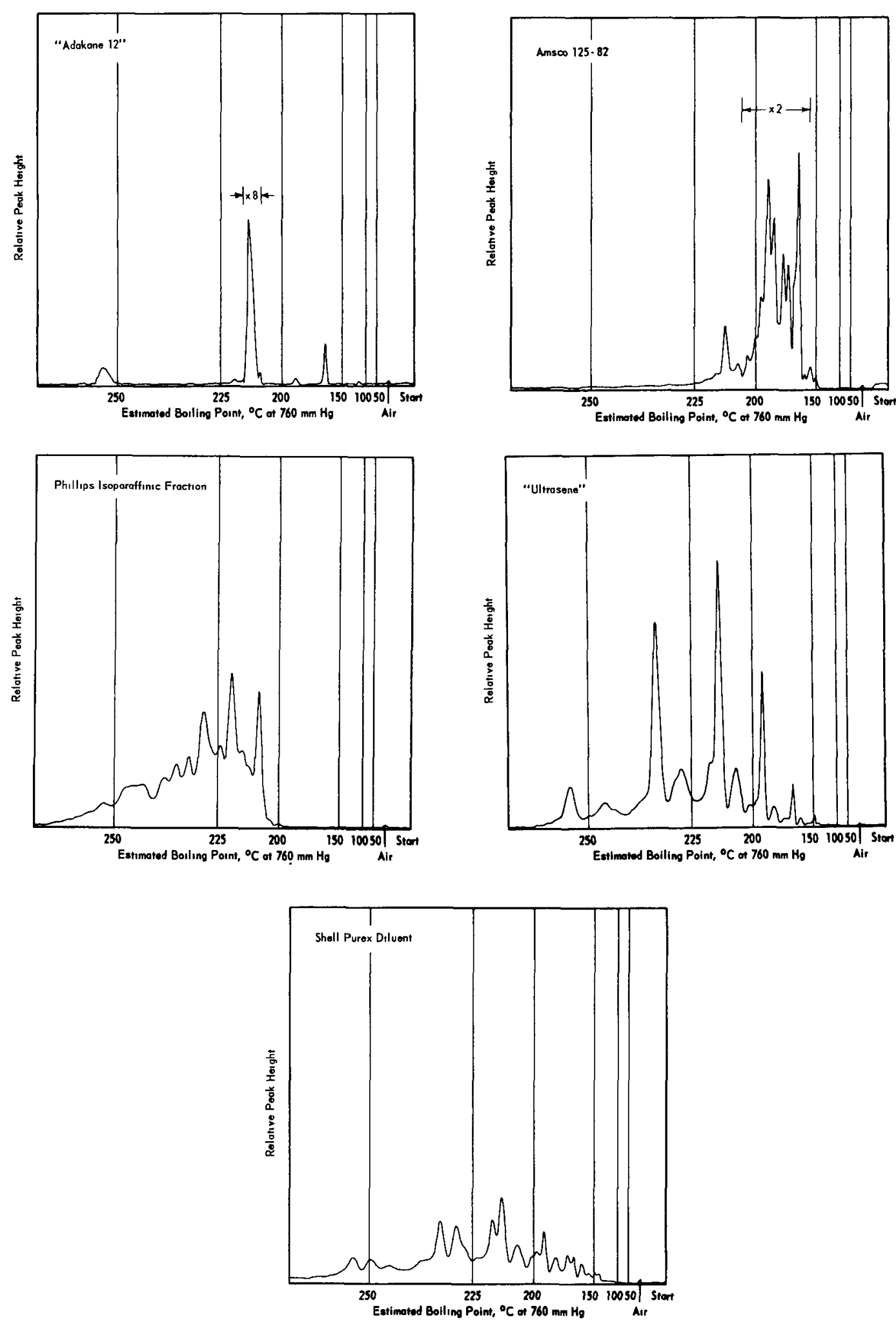

FIG. A- I GAS CHROMATOGRAMS OF DILUENTS FROM RADIOCHEMICAL SEPARATIONS PLANTS 

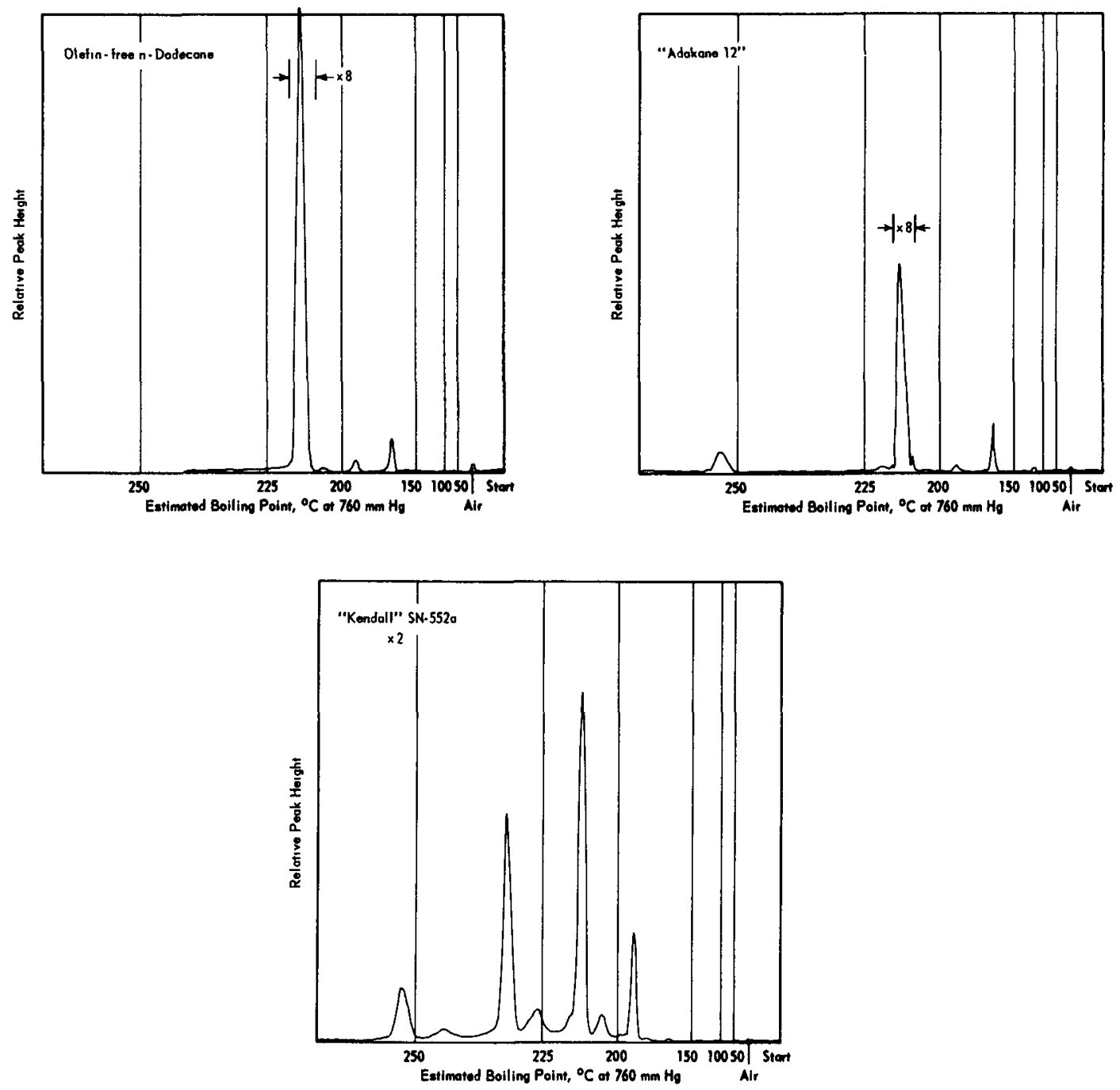

FIG. A-2 GAS CHROMATOGRAMS OF $n$-PARAFFIN MIXTURES 

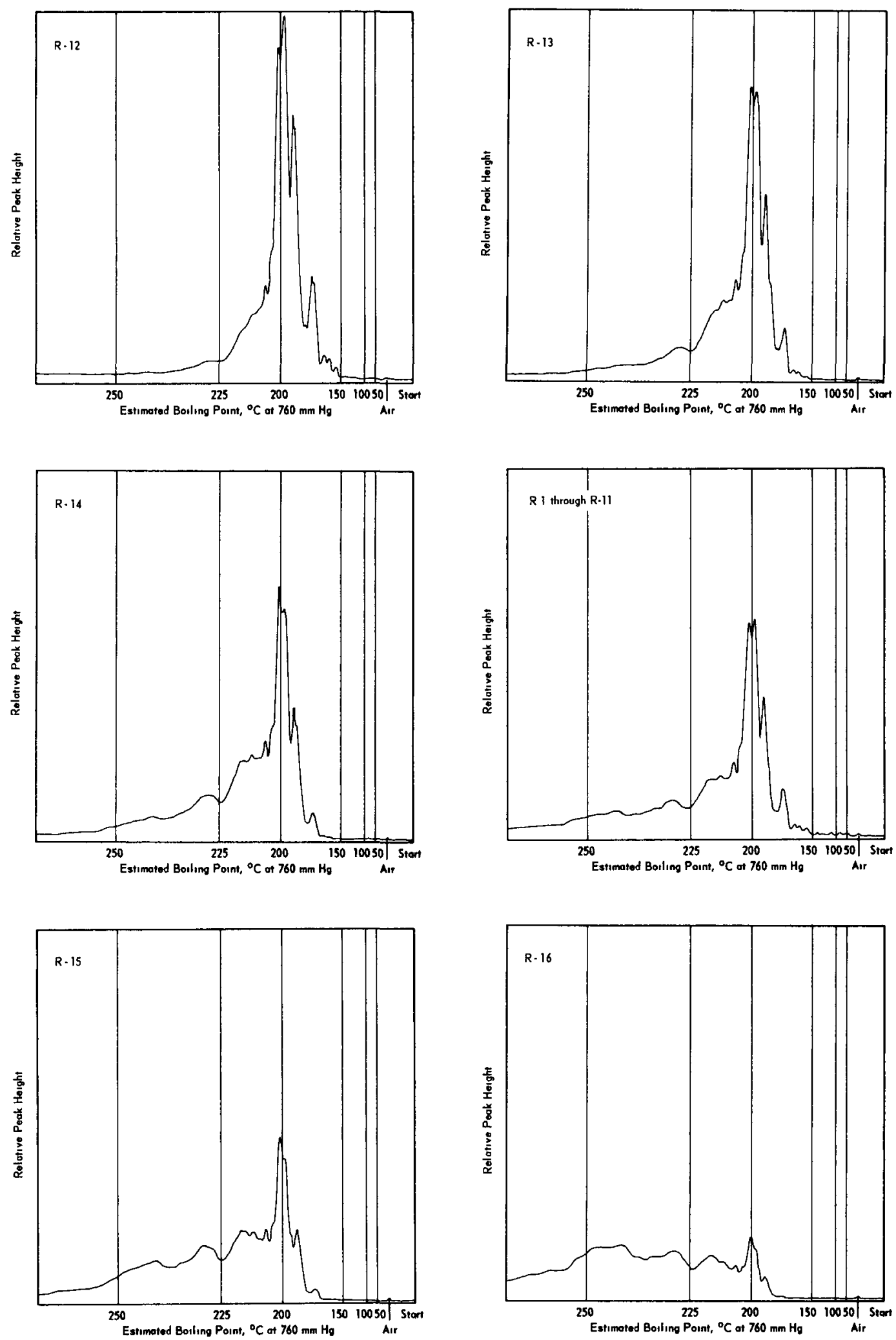

FIG. A- 3 GAS CHROMATOGRAMS OF DISTILLATION FRACTIONS OF AN ISOPARAFFIN MIXTURE (from Ashland Oil \& Refining Co.) 

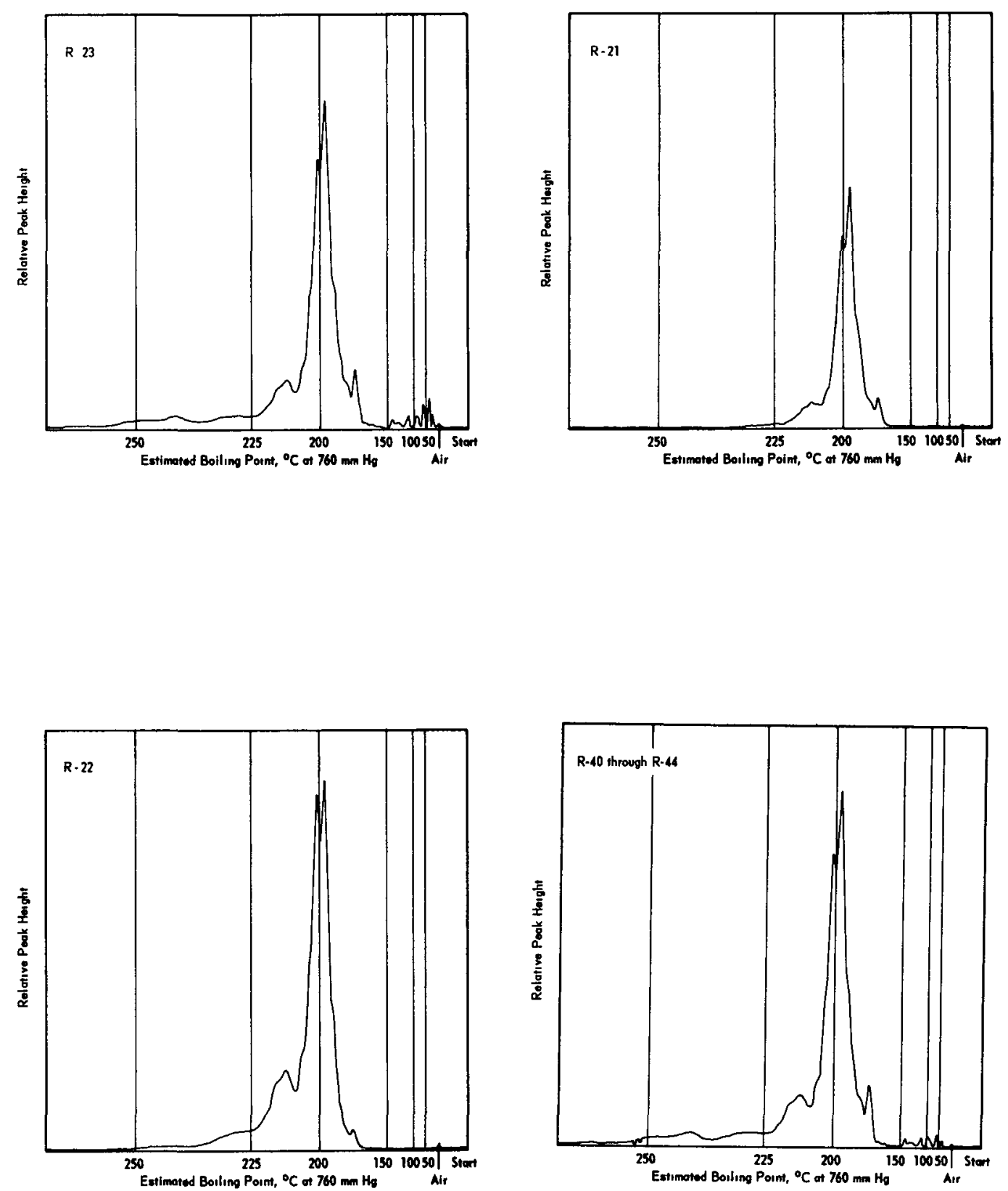

FIG. A - 4 GAS CHROMATOGRAMS OF ISOPARAFFIN MIXTURES (from Ashland Oil \& Refining Co.) 

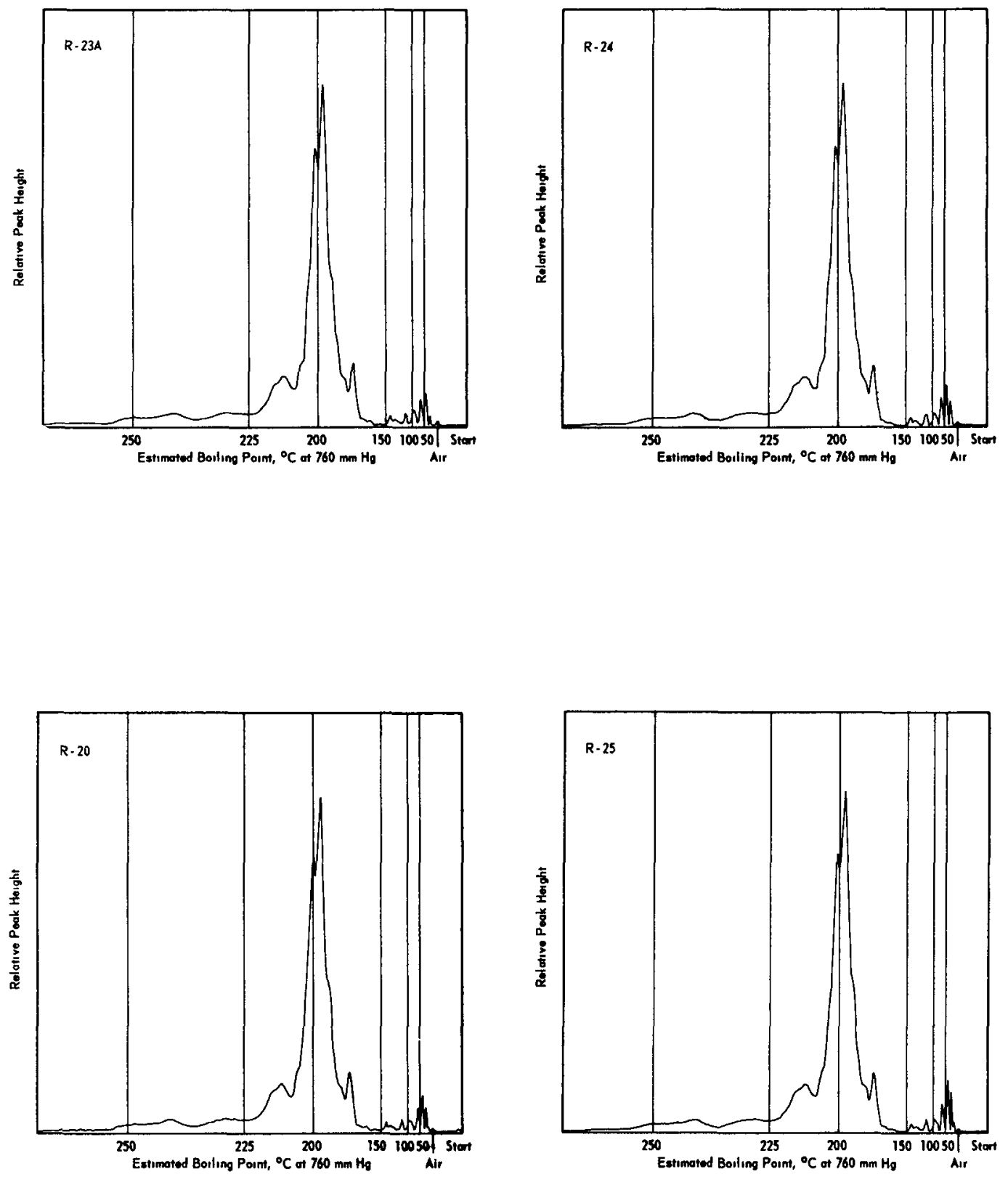

- $19-$ 

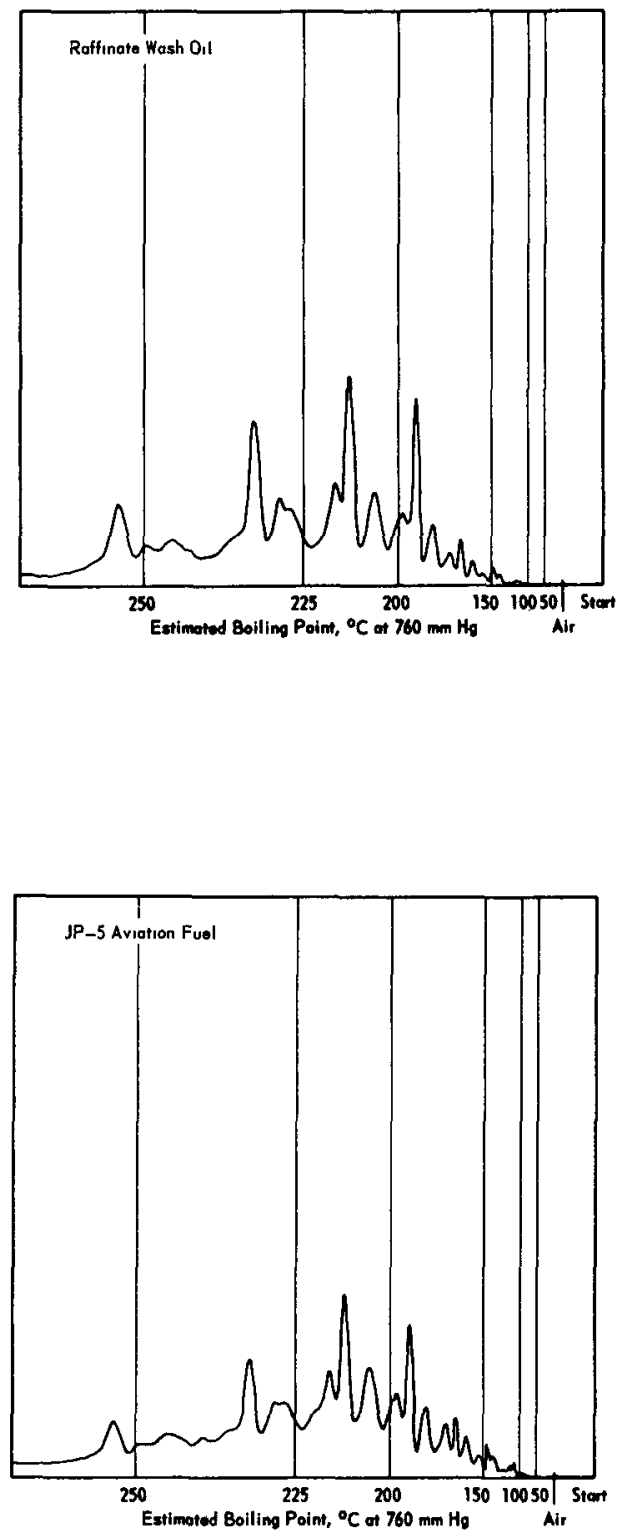

FIG. A - 5 GAS CHROMATOGRAMS OF HIGH BOILING HYDROCARBONS 

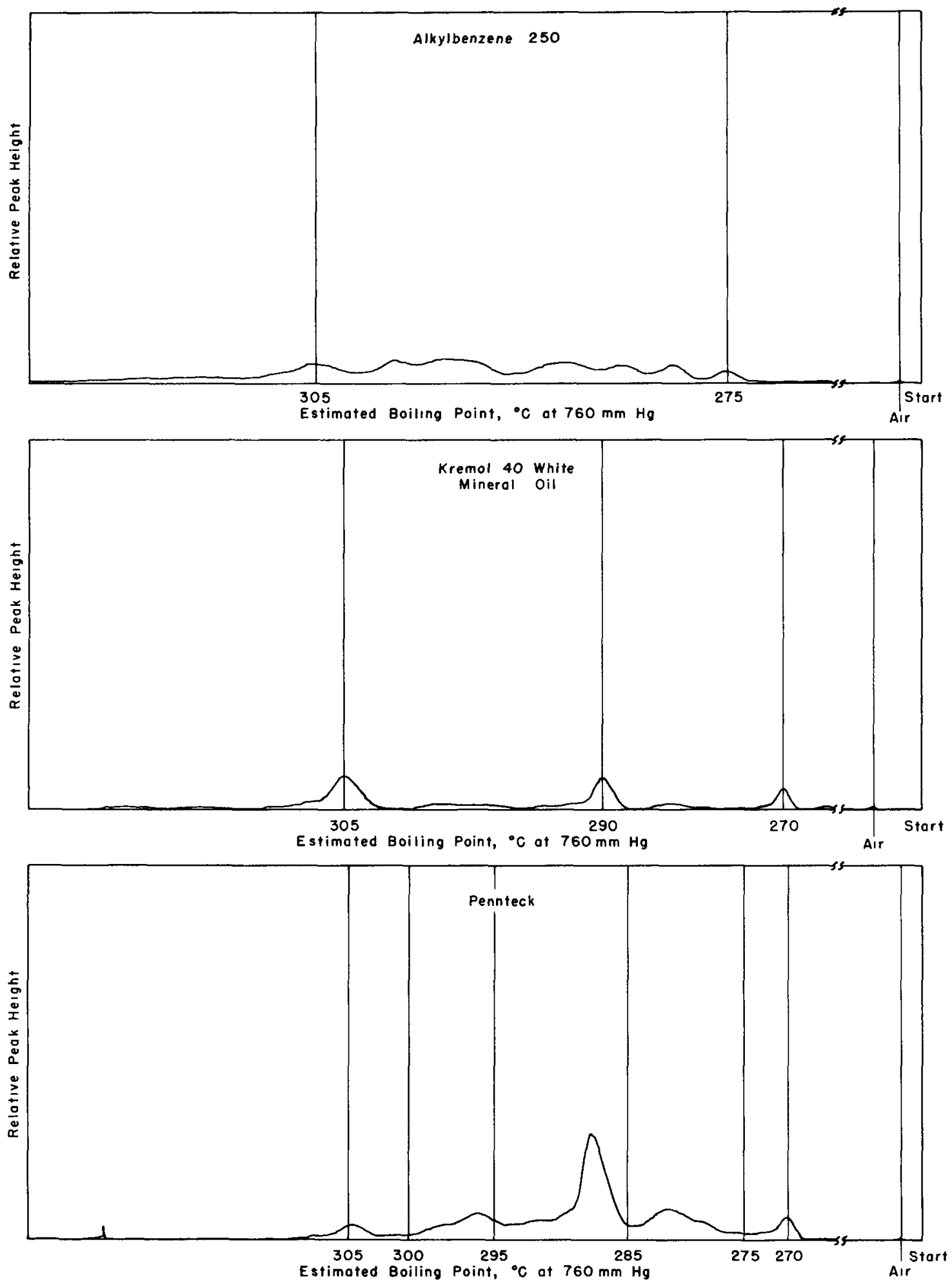

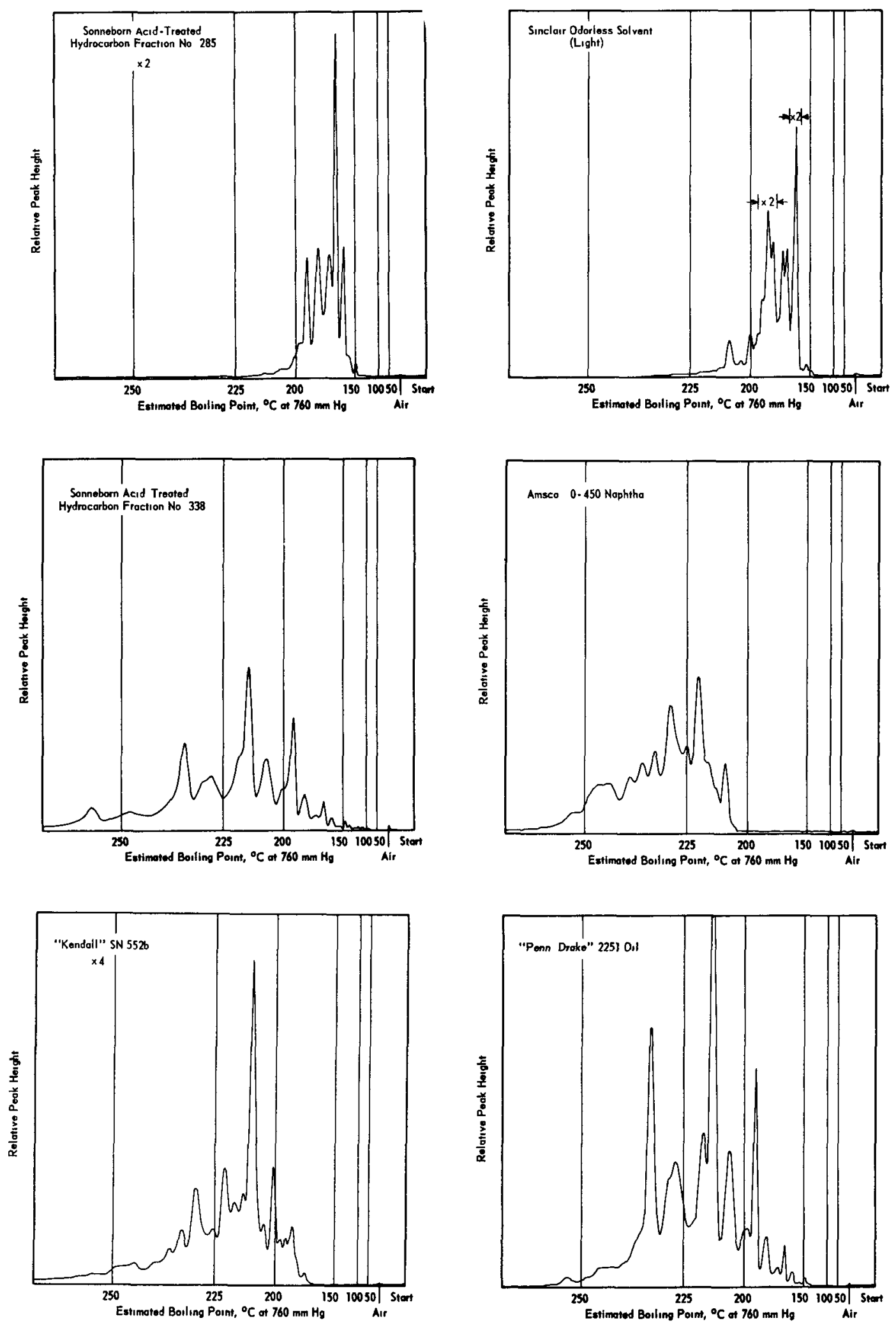

FIG. A- 6 GAS CHROMATOGRAMS OF OTHER CANDIDATE DILUENTS 

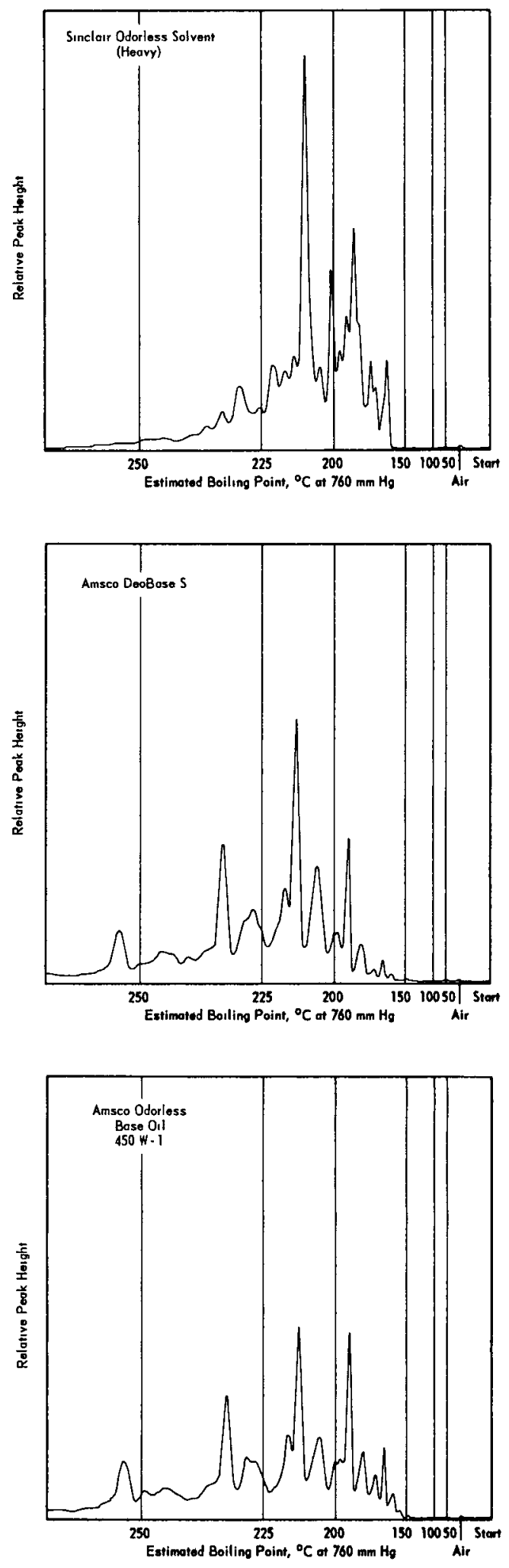


\section{APPENDIX B}

\section{INFRARED SPECTROGRAMS OF SELECTED DILUENTS}

Infrared spectra were measured elther on those candidate diluents that exhibited a more favorable degree of stability or on those that are used in radiochemical separations processes at other sites. The spectra were recorded from 2 to $15 \mu$ on a Perkin-Elmer Model 221 Spectrophotometer equipped with a sodium chloride prism. A sodium chlorlde plate was placed in the reference beam to compensate for reflectance losses. The cell thickness is shown on each spectrogram.

When considered in confunction with the manufacturer's literature and the chromatograms of Appendix A, these infrared data provide useful information on the gross composition and purity of the hydrocarbon mixtures evaluated. For example, the percentage of normal paraffins present may be deduced from the relative intensity of the band that appears at $13.9 \mu$ for molecules with more than four methylene (- $\mathrm{CH}_{2}-$ ) groups in series.

The supplier of each diluent is 1 isted in Table I. 


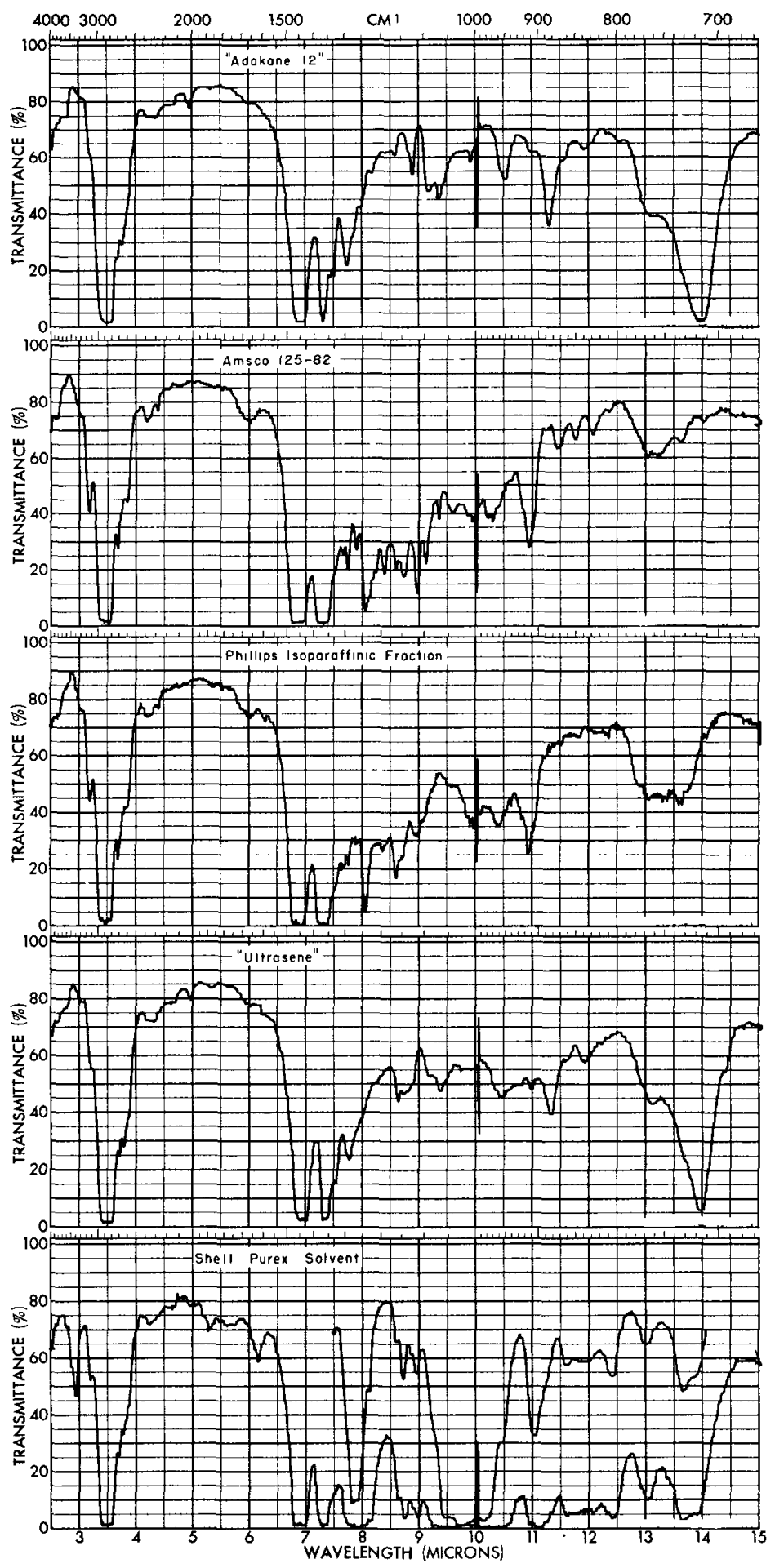

FIG. B- I IR SPECTROGRAMS OF DILUENTS FROM RADIOCHEMICAL SEPARATIONS PLANTS 


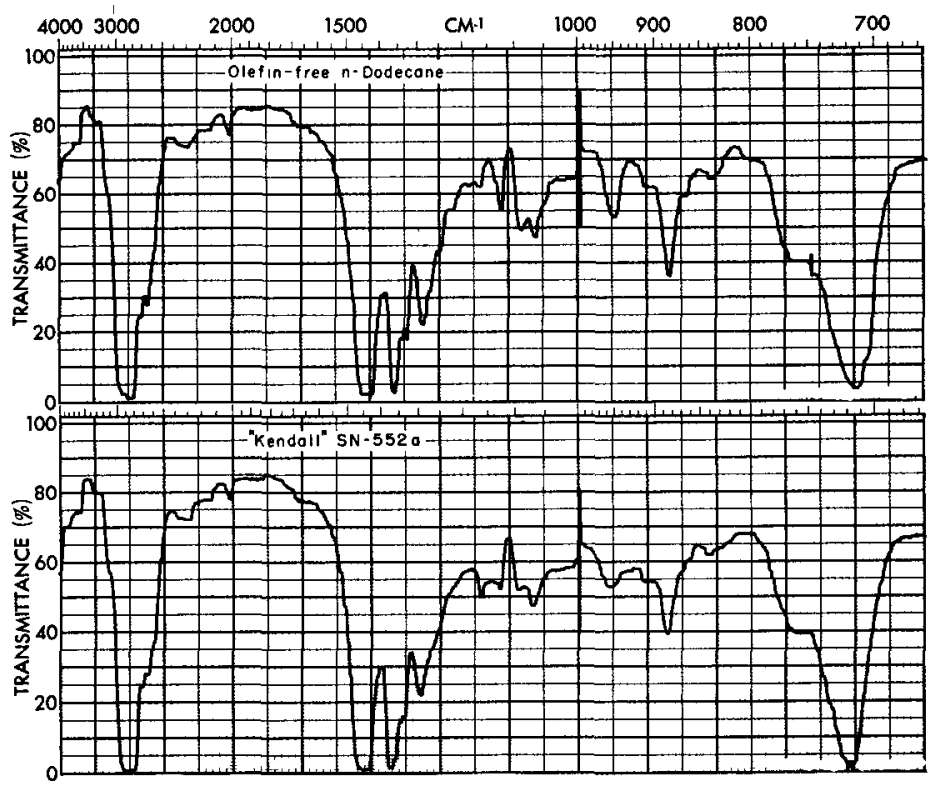

FIG. B - 2 IR SPECTROGRAMS OF $n$-PARAFFIN MIXTURES

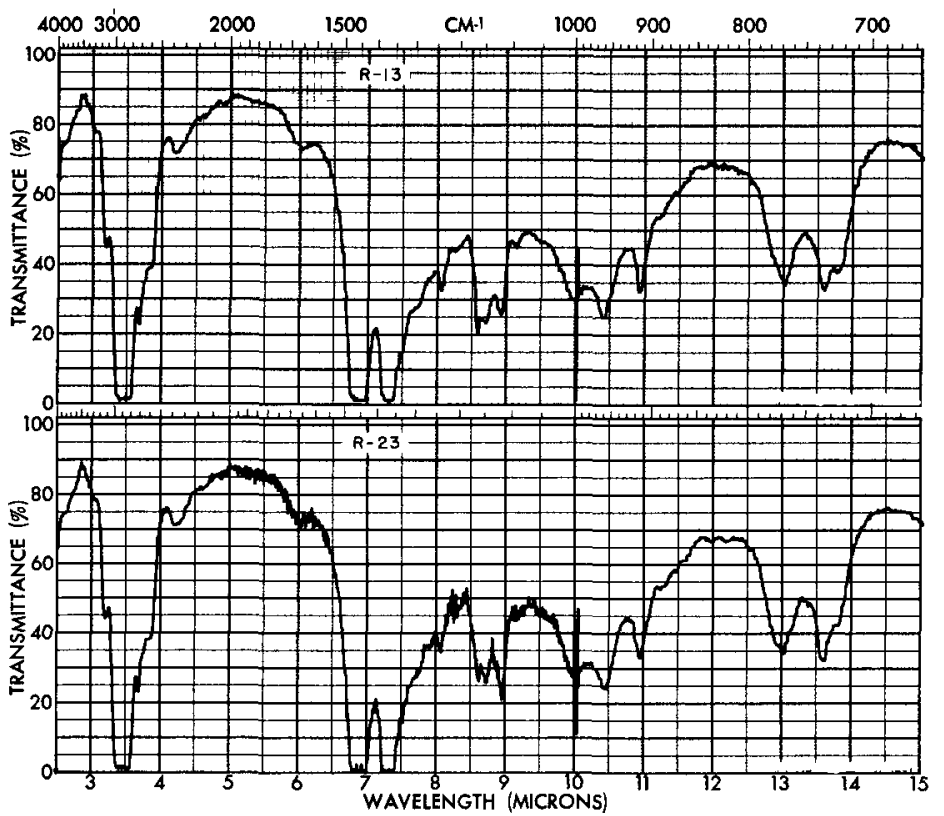

FIG. B-3 IR SPECTROGRAMS OF ISOPARAFFIN MIXTURES (from Ashland Oil \& Refining Co.) 



\section{APPENDIX C}

\section{ULTRAVIOLET SPECTROGRAMS OF SELECTED DILUENTS}

As with the infrared spectra, ultraviolet spectra were measured on candidate diluents of interest because of high stability or known use in radiochemical plants at other AEC sites. The samples were measured from 4000 to $2000 \AA$ in $1-\mathrm{cm}$ cells (unless otherwise indicated) against 1sooctane with a Cary Recording Quartz Spectrophotometer Model 11 at a scanning rate of $300 \AA /$ inch.

These ultraviolet spectra were used to ensure the absence of aromatic or confugated olefinic compounds, which are known to be deleterious to chemical or radiolytic stability. They also served to ensure the absence of organic compounds such as acetone, that are commonly used to clean and dry laboratory glassware and sample containers.

The supplier of each diluent is Iisted in Table I. 


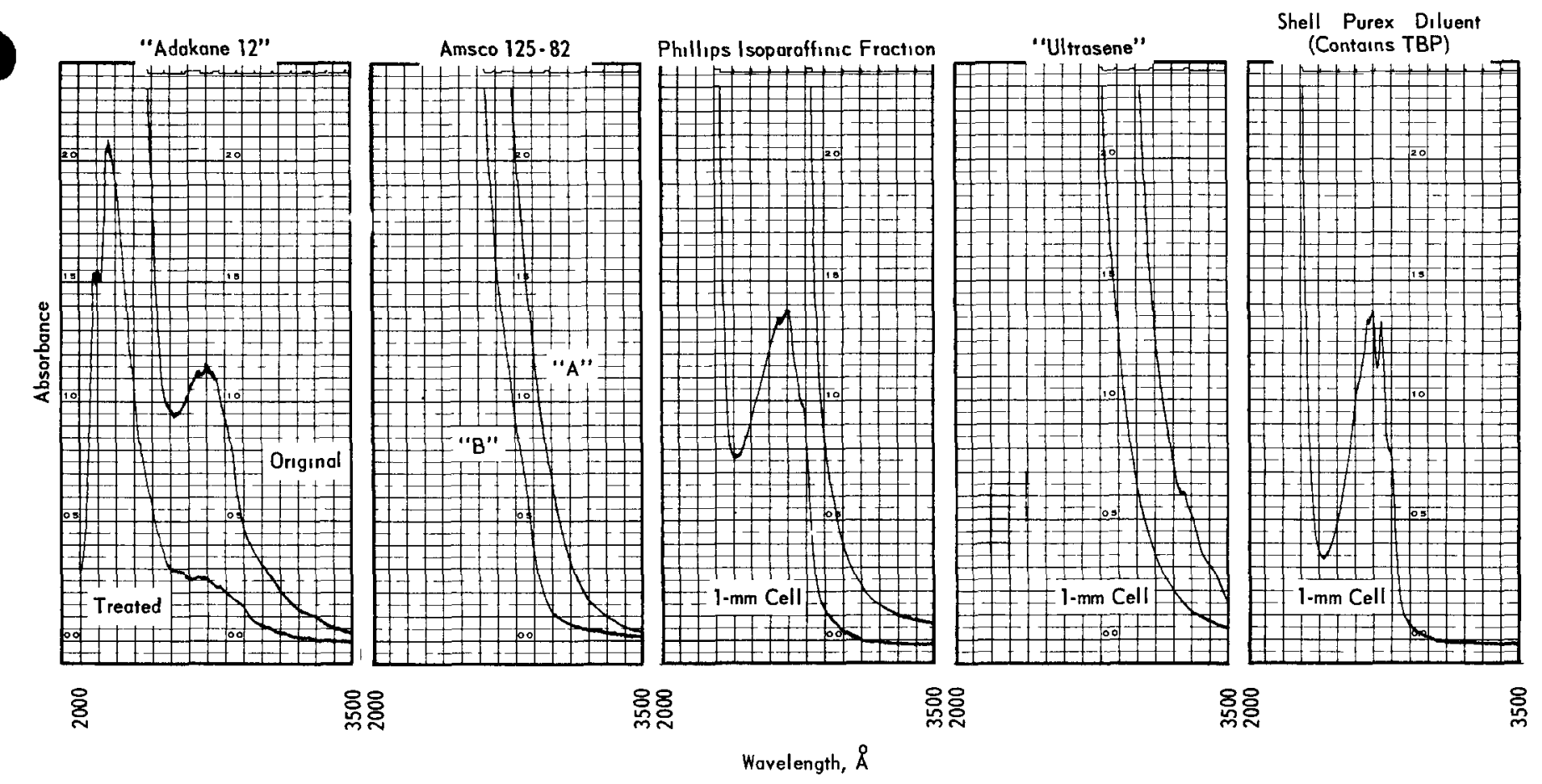

FIG C- 1 UV SPECTROGRAMS OF DILUENTS FROM RADIOCHEMICAL SEPARATIONS PLANTS

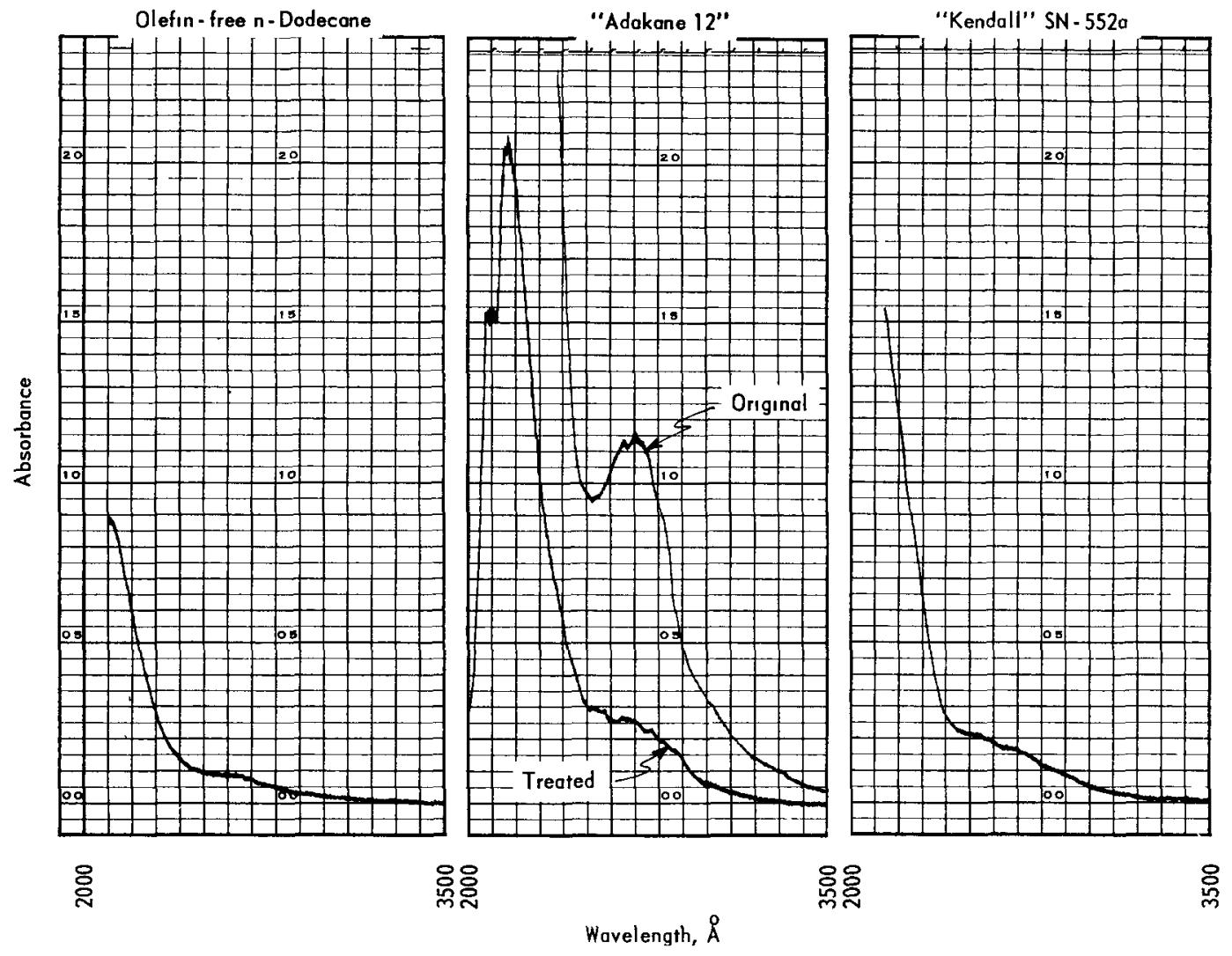

FIG. C - 2 UV SPECTROGRAMS OF $n$-PARAFFIN MIXTURES 
$\mathrm{R} \cdot 13$

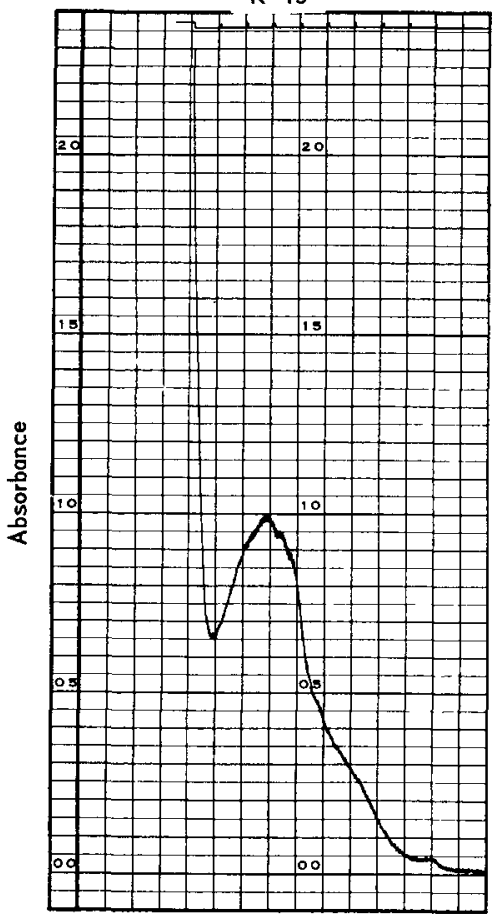

$R-23$

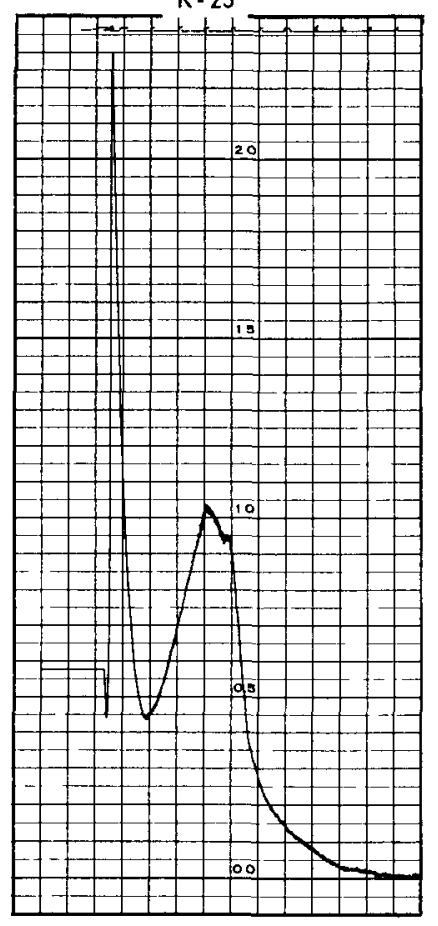

Wavelength, $\AA$
R- 21

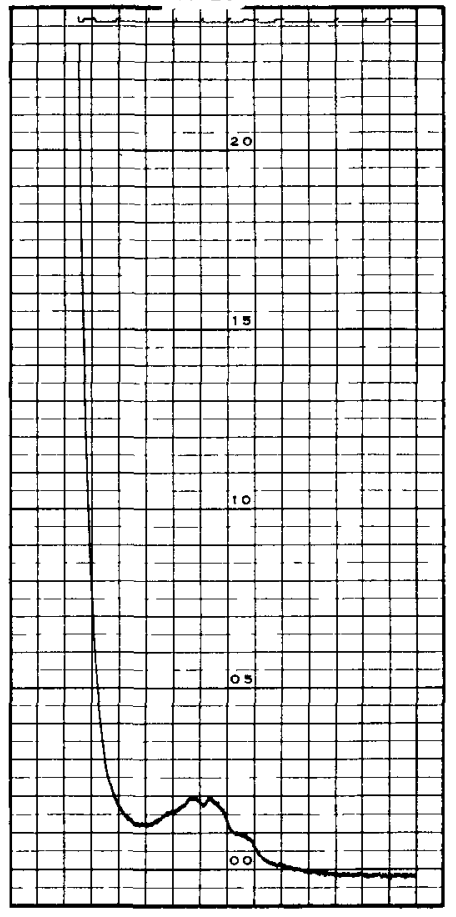

옳유

总

FIG. C- 3 UV SPECTROGRAMS OF ISOPARAFFIN MIXTURES (from Ashland Oil \& Refining Co.)
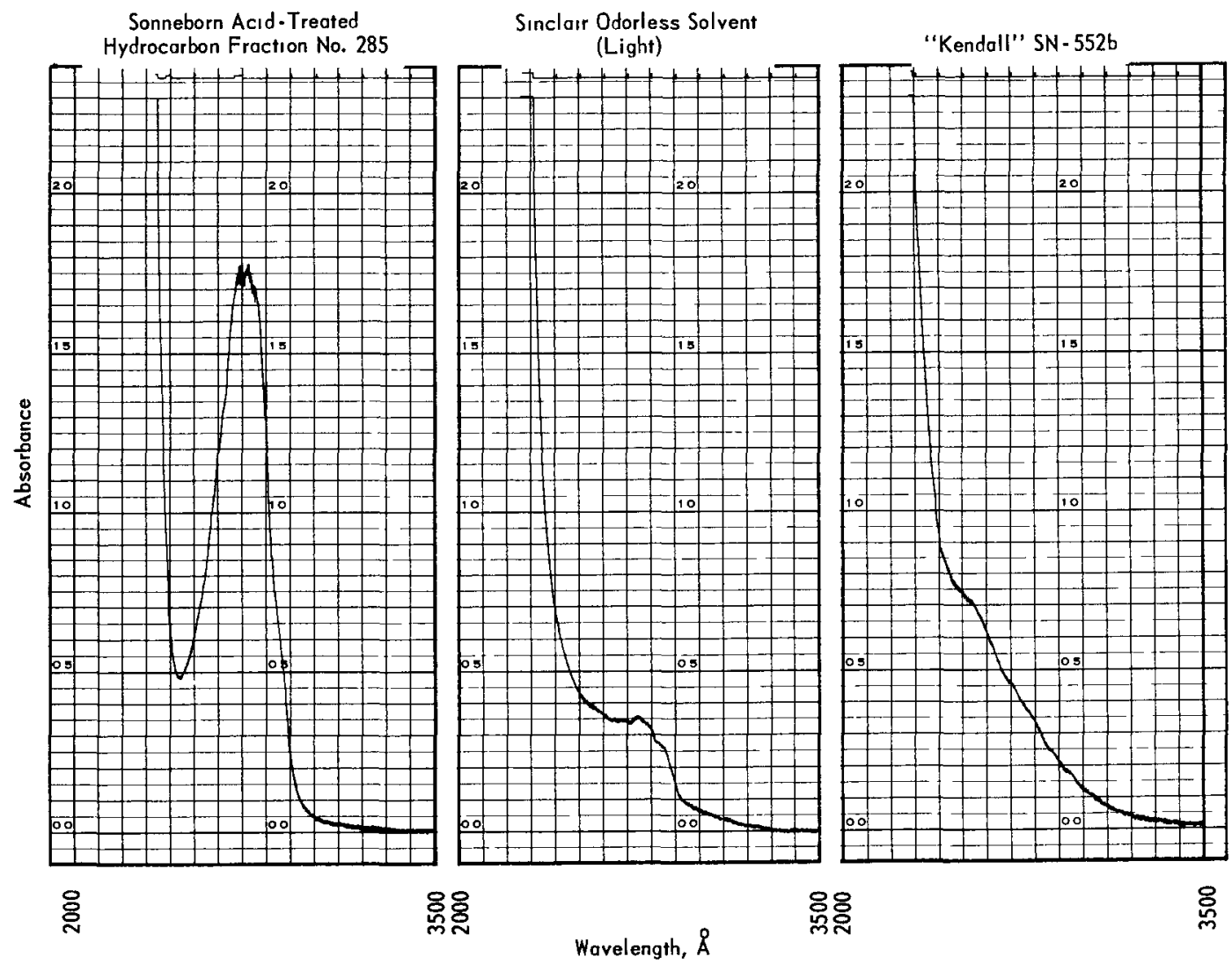

总

FIG. C-4 UV SPECTROGRAMS OF OTHER CANDIDATE DILUENTS 
APPENDIX D

STATISTICAL ANALYSIS OF STABILITY RATIOS

\begin{tabular}{|c|c|c|c|c|c|c|}
\hline & $\begin{array}{l}\text { Stab111ty } \\
\text { Chem1cal }\end{array}$ & $\begin{array}{r}\text { Rat } 10 \\
\text { Degrad }\end{array}$ & (a) & $\begin{array}{l}\text { Stab11 } \\
\text { Radiol } \\
\end{array}$ & $\begin{array}{l}\text { y Rat10 } \\
\text { 1c Degr }\end{array}$ & $\begin{array}{l}\text { ter } \\
\text { tion }\end{array}$ \\
\hline Description & $\overline{\bar{x}}$ & $\mathrm{~s} / \sqrt{\mathrm{n}}$ & $\bar{n}$ & $\bar{x}$ & $\mathrm{~s} / \sqrt{n}$ & $n$ \\
\hline $\begin{array}{l}\text { Olef1n-free n-Dodecane } \\
\text { (Control) }\end{array}$ & 1 & & & 1 & & \\
\hline "Adakane $12 "$ & I & 0.2 & 9 & 0.6 & - & 1 \\
\hline Amsco $125-82$ & 4 & 1 & 3 & 0.56 & 0.10 & 5 \\
\hline Ashland $\mathrm{R}-12$ & 4 & 1 & 2 & 0.76 & 0.075 & 2 \\
\hline Ashland R-13 & 6 & 1 & 2 & 1.0 & 0.1 & 2 \\
\hline Ashland R-23 & 10 & 2 & 4 & 0.61 & 0.18 & 4 \\
\hline Ashland $\mathrm{R}-21$ & 11 & 2 & 6 & 0.42 & 0.04 & 6 \\
\hline $\begin{array}{l}\text { Sonneborn Ac1d-Treated } \\
\text { Hydrocarbon Fraction No. } 285\end{array}$ & 12 & 1 & 2 & 0.8 & 0.4 & 2 \\
\hline $\begin{array}{l}\text { Sincla1r Odorless Solvent } \\
\text { (Light) }\end{array}$ & 14 & 4 & 2 & 0.31 & 0.01 & 2 \\
\hline "Kendall" SN-552b & 15 & 2 & 2 & 0.8 & - & 1 \\
\hline Ashland $\mathrm{R}-14$ & 15 & 1 & 2 & 1.2 & 0.1 & 2 \\
\hline Ashland R-22 & 20 & 5 & 3 & 0.56 & 0.12 & 4 \\
\hline Ashl and $R-40$ through $R-44$ & 20 & 5 & 20 & 0.80 & 0.01 & 20 \\
\hline Ashland $R-23 A$ & 20 & 4 & 2 & 1.1 & 0.6 & 2 \\
\hline Ashl and R-24 & 25 & 4 & 4 & 0.6 & 0.1 & 4 \\
\hline Ashl and $R-25$ & 25 & 6 & 2 & 0.9 & 0.2 & 4 \\
\hline Ashland R-1 through R-1l & 25 & 2 & 20 & 0.90 & 0.01 & 20 \\
\hline Alkylbenzene 250 & 25 & 2 & 2 & 3.7 & 0.1 & 2 \\
\hline $\begin{array}{l}\text { Sonneborn Ac1d-Treated } \\
\text { Hydrocarbon Fraction No. } 338\end{array}$ & 30 & 5 & 2 & 2 & - & 1 \\
\hline Ashland $\mathrm{R}-15$ & 30 & 8 & 2 & 1.8 & 0.1 & 2 \\
\hline Ashl and $R-20$ & 50 & 13 & 6 & 0.54 & 0.09 & 6 \\
\hline Amsco $0-450$ Naphtha & 50 & 4 & 4 & 1.6 & 0.3 & 2 \\
\hline "Kendall" SN-552a & 50 & 7 & 2 & 1.6 & - & 1 \\
\hline Ph1llips Isoparaffinic Fraction & 50 & 7 & 2 & 1.2 & - & 1 \\
\hline Ashland R-16 & 50 & 10 & 2 & 2.7 & 0.1 & 2 \\
\hline "Penn-Drake" 2251011 & 80 & 20 & 2 & 1.5 & 0.2 & 2 \\
\hline Raffinate wash 011 & 100 & 50 & 2 & 4 & 2 & 2 \\
\hline $\begin{array}{l}\text { Sincla1r Odorless Solvent } \\
\text { (Heavy) }\end{array}$ & 130 & 60 & 2 & 1.7 & 0.1 & 2 \\
\hline "Ultrasene" & 150 & 30 & 10 & 2.8 & 0.3 & 10 \\
\hline Kremol 40 White M1neral 011 & 200 & - & 1 & 0.5 & - & 1 \\
\hline Amsco DeoBase $S$ & 200 & 70 & 2 & 4.6 & 0.5 & 2 \\
\hline Shell Purex D1luent & 200 & 70 & 2 & 8 & 4 & 2 \\
\hline JP-5 Avlation Fuel & 250 & 40 & 2 & 3 & - & 1 \\
\hline $\begin{array}{l}\text { Amsco Odorless Base } 011 \\
450 \mathrm{~W}-1\end{array}$ & 250 & 15 & 2 & 5.6 & 0.1 & 2 \\
\hline Pennteck & 400 & 140 & 2 & 4.8 & 0.2 & 2 \\
\hline
\end{tabular}

(a) $\bar{x}$ is the average stab1lity ratio. $s$ is the standard deviation.

$\mathrm{n}$ is the number of determinations. 